\title{
ADAPTATION OF IPCC DEFAULT VALUES ON NATIONAL LANDFILL CONDITIONS
}

\author{
Kai-Uwe Heyer *, Karsten Hupe and Rainer Stegmann \\ IFAS, Ingenieurbüro für Abfallwirtschaft, Prof. R. Stegmann und Partner, Hamburg, Germany
}

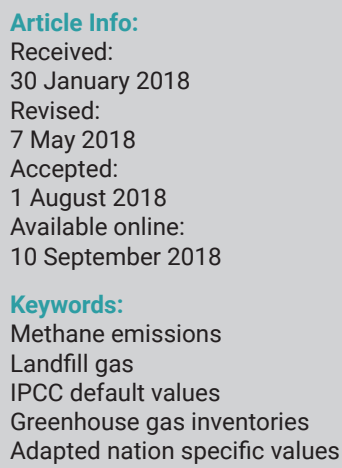

\begin{abstract}
Over the next 10 to 30 years methane emissions from landfills in Germany will continue to represent a major source of greenhouse-gas emissions in the waste sector. Methane emissions have been estimated for the National Inventory Report on the German Greenhouse Gas Inventory (NIR) using the First Order Decay (FOD) method and the IPCC Guidelines for National Greenhouse Gas Inventories. Both national data and default factors (standard values) provided by the IPCC were used in calculating the estimations. A review of the methodological basis and input data used to determine methane formation in landfills indicates that the previous approaches adopted in the NIR reports led to methane formation rates that clearly exceeded actual emissions from German landfills. Both the state of knowledge and the results of investigations focussed on landfill gas production and emissions from numerous German municipal solid waste landfills confirm the latter. To obtain a more accurate description of the methane generation potential and methane generation in landfills, DOC parameters, fraction of degradable organic carbon ( $\mathrm{DOC}_{\mathrm{f}}$ ), half-life and methane correction factor (MCF) can be adapted for the individual organic fractions of waste. When the adapted values for use in the estimation of methane emissions of German landfills are applied, the results yielded are in a range of approx. 50\% compared to the estimated values reported in the German NIR to date.
\end{abstract}

\section{INTRODUCTION}

Since the early 1990s a series of legal provisions have been issued pertaining to the waste-management sector in Germany, and a number of relevant organisational measures have been implemented. These moves have had a strong impact on trends in emissions from waste-landfilling. Relevant developments have included an intensified collection of biodegradable waste from households and the commercial sector, an intensified collection of other recyclable materials, such as glass, paper/cardboard, metals and plastics; separate collection of packaging; and recycling of packaging. In addition, incineration of settlement waste has been expanded, and mechanical biological treatment (MBT) of residual waste has been introduced. As a result of these measures, the amounts of landfilled settlement waste decreased very sharply from 1990 to 2006, and have been stabilising at a low level since 2006 (Figure 1). As the figure shows, more than half the settlement waste produced in Germany today is collected separately and gleaned for recyclable materials (separate collection of recyclable materials and biodegradable waste) (UBA, 2017).

In 2004, approx. 330 settlement waste landfills were in operation in Germany and strict legal regulations were implemented whereby this type of landfill was required to be equipped for the collection and treatment of landfill gas. These regulations were fundamental in extensively reducing methane emissions from such facilities. In June 2005, in keeping with new, stricter requirements, more than half of all existing landfills were closed. As a result, as few as 150 settlement waste landfills remain in operation today. Pursuant to regulations in force since June 2005, the landfilling of biodegradable waste is no longer permitted, thus wastes with a potential for significant methane formation cannot be landfilled. To comply with the relevant requirements, settlement and other biodegradable wastes should undergo pretreatment by means of thermal or mechanical biological processes. From the year 2006, only a few waste components present in landfilled waste, with a minimal methane-formation potential (such as residues from treatment in MBT facilities) have contributed to the formation of landfill gas. As the formation of landfill gas in older landfills decreases, methane emissions from landfills will likewise decrease extensively, in the long term stabilising at very low levels (UBA, 2017).

By reducing landfill methane emissions from 1.4 million $\mathrm{Mg} \mathrm{CH}_{4}$ in 1990 to 0.4 million Mg in 2014, the waste-man- 


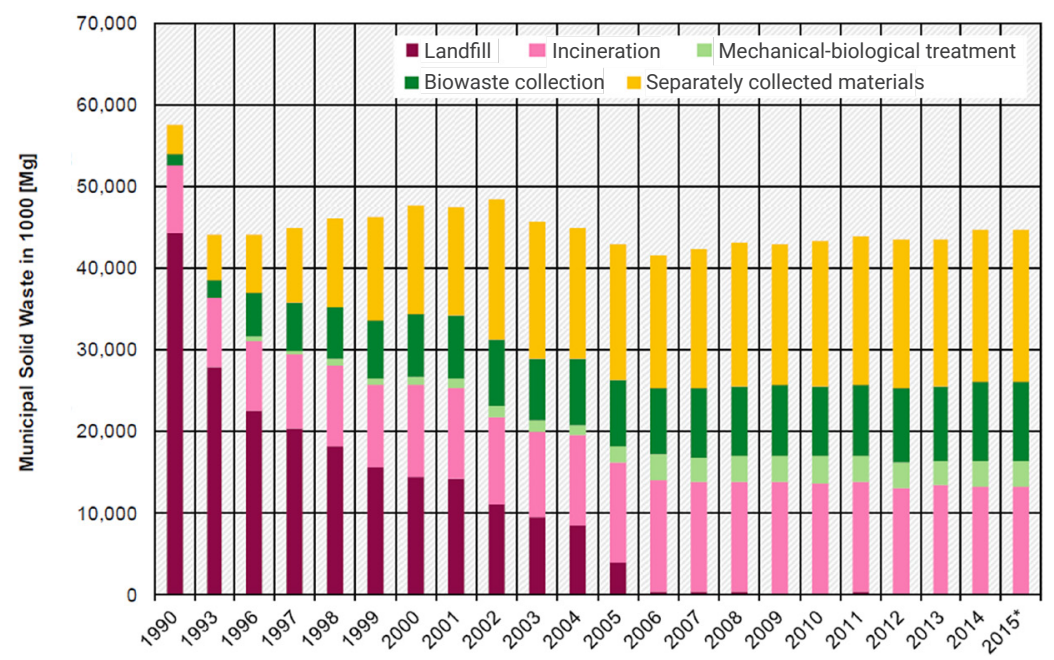

FIGURE 1: Changes in pathways for management of settlement waste from 1990 to 2015, with intermediate years (UBA, 2017).

agement sector in Germany has made an important contribution to climate protection (Figure 2). The lower methane emissions amount to a decrease of 24 million tonnes of $\mathrm{CO}_{2}$ equivalents per year and, thus, to a $2.2 \%$ reduction of Germany's entire greenhouse-gas emissions. Experience gained by Germany's waste-management sector shows that a reduction in the quantities of biodegradable waste landfilled will provide a significantly higher contribution to climate protection than the collection and treatment of landfill gas.

Although the landfilling of biodegradable waste in Germany has been prohibited since June 2005, methane emissions from landfills will remain a major source of greenhouse-gas emissions in the waste sector for the foreseeable future.

Methane emissions from landfills were estimated for the National Inventory Report on the German Greenhouse Gas Inventory (NIR) using the First Order Decay method (FOD method) according to the IPCC Guidelines for National Greenhouse Gas Inventories. Calculations were based on data and factors assigned to the waste at the time of deposition, as well as by modelling biological degradation over the deposition period. Both national data and default factors (standard values) of the IPCC were used for the calculation.

To quantify methane emissions, the amount of methane extracted should be subtracted from the amount of methane generated. Based on the data collected by the German Federal Statistical Office on the amount of methane captured for the entire landfill status in 2014, the average collection rate corresponds to approx. $24 \%$, very low in comparison to international rates (Figure 2) (Oonk, 2012, Krause et al., 2016). Consequently, questions were raised on the validation of the FOD method to produce more realistic estimates of the formed methane and its quantities. Therefore, the objective of a research project for the German Federal Environmental Agency was to investigate the estimation of landfill gas generation and emission (IFAS \& RUK, 2017) and validate the same.

The-project comprises the following tasks:

- Verification of the estimation of landfill gas formation.
For this purpose, the results of an initial expert report (RUK, 2014) are to be reviewed and updated;

- Verification of former MSW landfill sites to investigate gas quality and quantity, with sampling of solid wasteand determination of the residual gas formation potential; - Investigations on the gas formation potential of fresh waste at laboratory scale;

- According to the analytical results, potential adjustments and modifications of the estimated actual gas production rates using the FOD method will be determined and subsequently applied.

The current state of the report and the investigations are presented herein. The project has not yet been completed. The main aim of the research project and this paper is to develop a revised and improved set of values to be applied in the anaerobic degradation of relevant organic fractions such as food waste, garden waste, paper, wood, textiles or sludge, with particular regard to the following parameters:

- Degradable organic carbon in the landfilled waste (DOC);

- Fraction of degradable organic carbon which is anaerobically decomposed under landfill conditions ( $\mathrm{DOC}_{\mathrm{f}}$ ) half-life $\left(\mathrm{t}_{1 / 2}\right)$

- Methane correction factor (MCF)

\section{MATERIAL AND METHODS - GAS PROGNO- SIS, APPLICATION TO GERMAN LANDFILLS}

\subsection{Gas prognosis according to FOD method of the IPCC}

According to the IPCC Guidelines for National Greenhouse Gas Inventories (IPCC, 2006), the following formula applies to the methane formation potential Lo of a landfilled waste:

$\mathrm{Lo}=\mathrm{W} * \mathrm{DOC}^{*} \mathrm{DOC}_{\mathrm{f}} * \mathrm{MCF} * \mathrm{~F} * 16 / 12$

Lo = Methane formation potential $\left[\mathrm{Gg} \mathrm{CH}_{4}\right]$

$\mathrm{W}=$ Mass of landfilled waste [Gg waste] 


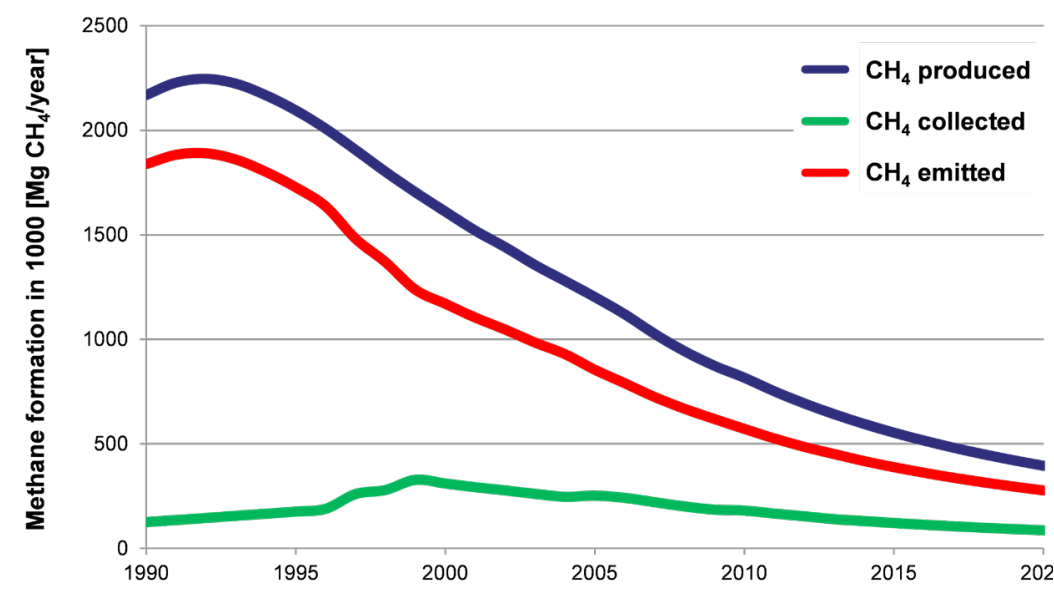

FIGURE 2: Impacts of waste management measures on the formation and emission of methane from landfills (Butz, 2014).

DOC $=$ Fraction of degradable organic carbon in the landfilled waste in the year of landfilling $[\mathrm{GgC} / \mathrm{Gg}$ waste] $\mathrm{DOC}_{\mathrm{f}}=$ Fraction of degradable organic carbon which is anaerobically decomposed under the conditions prevailing in the landfill [-]

MCF $=$ Methane correction factor [-]

$1-\mathrm{MCF}=$ Fraction of degradable organic carbon which is aerobically degraded

in the year of landfilling [-]

$\mathrm{F}=$ Methane concentration in the formed landfill gas $[-](0.5)$ $16 / 12$ = Molecular weight ratio $\mathrm{CH}_{4} / \mathrm{C}[-]$

The anaerobically degraded carbon quantity per year is estimated as follows:

DDOCm decomp $_{\mathrm{T}}=$ DDOCma $_{\mathrm{T}-1} *\left(1-\mathrm{e}^{-\mathrm{k}}\right)$

$\mathrm{T}=$ Year for which the calculation is performed

DDOCma $_{\mathrm{T}-1}=$ Available DDOCm in the landfill body by the end of year $\mathrm{T}-1[\mathrm{Gg}]$

DDOCm decompT = Anaerobically degraded DDOCm in year $\mathrm{T}[\mathrm{Gg}]$

$\mathrm{k}=$ Degradation constant $[1 / \mathrm{a}]$

$=\ln (2) / t_{1 / 2}$

$\mathrm{t}_{1 / 2}=$ Half-life $[\mathrm{a}]$

The methane produced from the degraded organic carbon $\left(\mathrm{DDOCm}\right.$ decomp $\left._{\mathrm{T}}\right)$, can be calculated as follows:

$\mathrm{CH}_{4}$ generated $_{\mathrm{T}}=$ DDOCm decomp $_{\mathrm{T}} * \mathrm{~F} * 16 / 12$

$\mathrm{CH}_{4}$ generated ${ }_{\mathrm{T}}=$ Quantity of methane formed in year $\mathrm{T}[\mathrm{Gg}$ methane]

By applying the FOD-model, the quantity of methane emitted during the considered year is calculated as follows:

$\mathrm{CH}_{4}$ emitted $_{\mathrm{T}}=\left(\mathrm{CH}_{4}\right.$ generated $\left._{\mathrm{T}}-\mathrm{RT}\right) *\left(1-\mathrm{OX}_{\mathrm{T}}\right)$

$\mathrm{CH}_{4}$ emitted $\mathrm{T}_{\mathrm{T}}=$ Amount of methane emitted in year $\mathrm{T}[\mathrm{Gg}$ methane]

$\mathrm{R}_{\mathrm{T}}=$ Amount of collected and combusted methane $[\mathrm{Gg}$ methane]

$\mathrm{OX}_{\mathrm{T}}=$ Fraction of methane oxidized in the landfill covering layer [-]

\subsection{German NIR standard values and first preceding modification}

In a previous expert report, standard values from the German NIR 2014 were used and compared with the operating results of landfill gas collected from 5 fully encapsulated landfills. On this basis, values differing from the standard NIR values were set, to ensure that the predicted time course of landfill gas production accurately reflected the time course of the landfill gas actually collected (RUK, 2014).

Table 1 shows the different values for the half-life and DOC $_{f}$. As a comparison, the standard values of the German NIR used to date are listed.

Reasons for the previous adaptation:

- DOC $_{f}$-values: The approach used in the IPCC model, according to which $50 \%$ of degradable organic waste is consistently degraded under landfill conditions, represents an unrealistic case. The readily degradable waste fraction is indeed substantially larger than that of scarcely degradable waste. In addition, readily degradable waste is often deposited with a high water content, thus rendering dehydration unlikely. Wood in bulk waste deposits is often deposited in a very dry condition, thus implying the risk that the wood may not come into contact with water at all. Therefore, biodegradable carbon $\mathrm{DOC}_{f}$, and the fraction of paper and cardboard, were adjusted.

- Half-life: Experience with German landfills has shown how in phases with a high degradation potential, halflives ranging from 4 (at the beginning of the phase) to 7.5 years can be assumed (Rettenberger, 2004). By contrast, when the IPCC model is applied, all five landfills evaluated yielded a half-life of around 7 years or longer within the first year.

\section{EVALUATION OF GERMAN NIR VALUES AND RESULTS OF INVESTIGATIONS}

\subsection{Evaluation of $D O C$ and $D O C_{f}$ parameters for anaerobic degradation}

The DOC and $\mathrm{DOC}_{\mathrm{f}}$ values obtained are evaluated below. 
TABLE 1: Comparison of the present German NIR standard values (UBA, 2017) and modified values from a previous preliminary expert report (RUK, 2014).

\begin{tabular}{|c|c|c|c|c|}
\hline \multirow{2}{*}{ Waste fraction } & \multicolumn{2}{|c|}{$\begin{array}{l}\text { German NIR Approach } \\
\text { (UBA, 2017) }\end{array}$} & \multicolumn{2}{|c|}{$\begin{array}{l}\text { Previous Expert Report Approach } \\
\text { (RUK, 2014) }\end{array}$} \\
\hline & half-life (years) & $\mathrm{DOC}_{\mathrm{f}}$ & half-life (years) & $\mathrm{DOC}_{\mathrm{f}}$ \\
\hline Organic waste & 4 & 0,5 & 3 & 0,8 \\
\hline Garden and Park waste & 7 & 0,5 & 4 & 0,4 \\
\hline Paper and cardboard & 12 & 0,5 & 7 & 0,4 \\
\hline Wood and straw & 23 & 0,5 & 50 & 0,1 \\
\hline Textiles & 12 & 0,5 & 7 & 0,4 \\
\hline Disposable nappies & 12 & 0,5 & 7 & 0,4 \\
\hline Sewage sludge & 4 & 0,5 & 3 & 0,8 \\
\hline Composites & 12 & 0,5 & 7 & 0,4 \\
\hline MBT * - Waste & 12 & 0,5 & 12 & 0,5 \\
\hline
\end{tabular}

* Waste from mechanical biological treatment plants.

The IPCC standard default values and the slightly modified current German NIR approaches were compared with reference values from the literature and results of scientific investigations, mainly by means of lab-tests undertaken to determine gas formation potential.

The overview in Table 2 indicates the following:

- Compared to a large body of data from the literature, values used in the NIR report are relatively high;

- In the fraction "Food waste", DOC contents and their bioavailability $\left(\mathrm{DOC}_{\mathrm{f}}\right)$ are comparable;

- Garden waste yielded comparable results, although playing only a subordinate role in landfilling (self-composting, separate collection of green waste);

- Leaves (and woody shrub cuttings) as part of garden waste were characterised by a low bioavailability or anaerobic degradability $\left(\mathrm{DOC}_{\mathrm{f}}\right)$, in the range of $25 \%$ of NIR values;

- Literature data refer to a DOC range between 0.28 - 0.34 for paper and cardboard fraction, compared to the NIR value of 0.4 , also taking into account water content. Due to the high quantity of paper and cardboard deposited in German landfills, these parameters produce a significant influence on the estimation of methane emissions;

- Regarding the textile fraction, DOC contents are somewhat higher in the literature, although based on water contents of $15-25 \%$. Data relating to anaerobic degradability are not available for this single fraction. It is, however, to be assumed that this would be significantly below $50 \%\left(D O C_{f}=0.5\right)$, since a considerable carbon fraction is made up of plastic fibres;

- Digested sewage sludge, frequently disposed in the past, also displays a very low anaerobic degradability, in the range of $10-15 \%$ related to the NIR value of 0.5 ;

- The average DOC contents of three MSW sorting analyses in Bavaria and Austria from the period 1998-2003 are in a relatively narrow range of 128 to $132 \mathrm{kgC} / \mathrm{t} \mathrm{DM}$; thus, still below the average carbon content of the German nationwide domestic waste value from an analysis performed in 1985 (Barghoorn et al., 1986). Between the 1960s and up until termination of landfilling of unpretreated municipal waste in Austria and Germany, a gradual decrease of the carbon content of residual waste, derived from the various listed organic fractions but without plastic, has been determined;

- Application of the standard value of 0.5 (50\%) for all fractions is therefore unrealistic. The fraction of readily degradable waste is substantially higher than the fraction of scarcely degradable waste.

\subsection{Evaluation of the gas formation potential under anaerobic conditions}

In order to further assess the plausibility of NIR values, the gas formation potential, which can be derived from these NIR values for individual organic fractions as well as for the average value of the total organics, should be considered in detail.

Taking into account DOC values in the NIR and a DOC of 0.5 (Table 2), an average gas formation potential of $231 \mathrm{~m}^{3} / \mathrm{Mg}$ (wet matter) is obtained, as an example, for the deposited organic fractions in the year 1993, when a high quantity of organic waste was deposited in German landfills (quantity see Figure 1, composition see UBA, 2017). This average gas formation potential may then be compared with results of investigations focussing on gas formation potential, largely from the 1990s (Table 3 ).

This comparison with literature data indicates that the landfill gas formation potential resulting from NIR default or input values tends to be too high, and the actual conditions of landfill gas production on German landfills are not adequately quantified:

- Thus, the majority of data relating to organic waste fractions (food waste) and garden and park waste are below the gas formation potentials derived from the NIR values. A few significantly higher values were determined by lab-tests. However, these higher gas formation potentials e.g. for grass clippings (Ramke, 2010) exert only a minor effect on the total gas formation in landfills, due to the paucity of landfilling of grass clippings in German landfills;

- The difference observed for paper and cardboard fraction, for which the gas formation potential is only 
TABLE 2: Default values in the German NIR (UBA, 2017), reference results from literature and investigations (weight refers to wet mass).

\begin{tabular}{|c|c|c|c|c|c|}
\hline \multirow{2}{*}{ Waste type } & \multirow{2}{*}{$\begin{array}{c}\text { Approach } \\
\text { German NIR } \\
\text { DOC } \\
\text { (Mg C/Mg) }\end{array}$} & \multirow{2}{*}{$\begin{array}{c}\text { Approach } \\
\text { German NIR } \\
\text { DOC }_{f} \\
(-)\end{array}$} & \multicolumn{3}{|c|}{ Reference results literature, investigations etc. } \\
\hline & & & $\begin{array}{c}\text { DOC } \\
(\mathrm{Mg} \mathrm{C} / \mathrm{Mg})\end{array}$ & $\mathrm{DOC}_{\mathrm{f}}$ & Source \\
\hline \multirow[t]{4}{*}{ Food waste } & 0.18 & 0.5 & 0.09 & & Baumeler et al., 1998 \\
\hline & & & 0.167 & 0.571 & Ramke, 2010 \\
\hline & & & 0.172 & & BLfU, 2003 \\
\hline & & & 0.229 & & Nelles et al., 1998 \\
\hline \multirow[t]{2}{*}{ Garden } & 0.20 & 0.5 & 0.218 & 0.43 & Ramke, 2010 \\
\hline & & & 0.230 & 0.123 & Ramke, 2010 \\
\hline \multirow[t]{5}{*}{ Paper and cardboard } & 0.40 & 0.5 & 0.283 & & Nelles et al., 1998 \\
\hline & & & 0.296 & & BLfU, 2003 \\
\hline & & & 0.297 & & Nelles et al., 1998 \\
\hline & & & 0.30 & & Ramke, 2008 \\
\hline & & & 0.343 & & Baumeler et al., 1998 \\
\hline \multirow[t]{3}{*}{ Wood and straw } & 0.43 & 0.5 & 0.33 & 0.268 & Ramke, 2010 \\
\hline & & & 0.38 & 0.014 & Ramke, 2010 \\
\hline & & & 0.426 & & Baumeler et al., 1998 \\
\hline \multirow[t]{3}{*}{ Textiles } & 0.24 & 0.5 & 0.275 & & Nelles et al., 1998 \\
\hline & & & 0.275 & & BLfU, 2003 \\
\hline & & & 0.413 & & Baumeler et al., 1998 \\
\hline \multirow[t]{2}{*}{ Disposable nappies } & 0.24 & 0.5 & 0.167 & & BLfU, 2003 \\
\hline & & & 0.195 & & Nelles et al., 1998 \\
\hline Sewage sludge & 0.15 & 0.5 & 0.095 & 0.057 & Ramke, 2010 \\
\hline \multirow[t]{2}{*}{ Composites } & 0.10 & 0.5 & 0.22 & & Nelles et al., 1998 \\
\hline & & & 0.229 & & BLfU, 2003 \\
\hline MBP-Residues & 0.023 & 0.5 & & & \\
\hline \multirow[t]{4}{*}{ Municipal solid waste } & & & 0.137 & & Baumeler et al., 1998 \\
\hline & & & 0.128 & & Nelles et al., 1998 \\
\hline & & & 0.130 & & BLfU, 2003 \\
\hline & & & 0.20 & & Barghoorn et al., 1986 \\
\hline
\end{tabular}

$25-53 \%$ of NIR values, is particularly significant. The high assumptions in NIR are of considerable importance for the determination of methane emissions, since -in combination with the landfilled waste masses and selected half-life - these would theoretically dominate methane production in German landfills. Based on an average carbon content of $300 \mathrm{kgC} / \mathrm{t}(\mathrm{DOC}=0.3)$, the gas formation potential for paper fractions indicate an anaerobically degradable fraction of $28 \%\left(D_{0} C_{f}=\right.$ 0.28 , range $0.17-0.36$ )

- The discrepancy displayed by the gas formation potential for wood and straw fraction is even more significant, particularly with regard to wood, for which gas formation potentials of $5-14 \%$ based on the NIR gas formation potential were determined. Straw with a higher gas formation potential represented only a negligible mass fraction compared to wood;

- This basic tendency was also confirmed by comparison of the average gas formation potential of all individual organic fractions (NIR value: $231 \mathrm{~m}^{3} / \mathrm{t}$ ) from previous investigations of municipal solid and domestic waste. The gas formation potential determined in numerous investigations, generally determined under more favourable milieu conditions than in a real landfill (e.g. with regard to water balance, lack of aerobic degradation, etc.), ranged from $30-81 \%$ (average value $60 \%$ ) compared to the average gas formation potential according to NIR for the year 1993.

These results are fundamental in facilitating further adaptation of the input values for use in determining methane emissions from German landfills. Similar investigations should be performed in other countries.

\subsection{Evaluation of aerobic carbon degradation in landfills}

In addition to anaerobic processes, the biological degradation processes that occur in landfills are also characterized by aerobic degradation as follows:

- Immediately after deposition, aerobic degradation pro- 
TABLE 3: Landfill gas potential of organic fractions and landfilled waste (average gas potential of total organics in the reference year 1993) and comparison with reference results from laboratory scale investigations (all results refer to wet mass).

\begin{tabular}{|c|c|c|c|}
\hline \multirow{2}{*}{ Waste type } & \multirow{2}{*}{$\begin{array}{c}\text { German NIR (UBA, 2017) } \\
\left(\mathrm{m}^{3} / \mathrm{t}\right)\end{array}$} & \multicolumn{2}{|r|}{ Gas potential reference results } \\
\hline & & $\left(m^{3} / t\right)$ & Source \\
\hline \multirow[t]{3}{*}{ Food waste } & 168 & 110 & Kruse, 1994 \\
\hline & & 126 & Ramke, 2010 \\
\hline & & $76-168$ & Spendlin, 1991 \\
\hline \multirow[t]{5}{*}{ Garden waste } & 187 & 95 & Tallner, 1993 \\
\hline & & 105 & Ramke, 2010 \\
\hline & & $74-120$ & Kruse, 1994 \\
\hline & & 128 & Tallner, 1993 (different materials) \\
\hline & & 293 & Ramke, 2010 (different materials) \\
\hline \multirow[t]{4}{*}{ Paper } & 374 & $123-144$ & Kruse, 1994 (different materials) \\
\hline & & $95-159$ & Kruse, 1994 \\
\hline & & $158-182$ & Kruse, 1994 \\
\hline & & $168-201$ & Tallner, 1993 \\
\hline \multirow[t]{4}{*}{ Wood and straw } & 402 & 21 & Ramke, 2010 \\
\hline & & 44 & Tallner, 1993 \\
\hline & & $37.5-57$ & Kruse, 1994 \\
\hline & & 297 & Ramke, 2010 (shredded straw) \\
\hline Sewage sludge & 47 & 30 & Kruse, 1994 \\
\hline Composite materials & 93 & & \\
\hline $\begin{array}{l}\varnothing \text { Gas potential total organics } \\
\text { reference year } 1993\end{array}$ & 231 & & \\
\hline \multirow[t]{7}{*}{ Municipal solid / domestic waste } & & $70-126$ & Lechner, 2004 \\
\hline & & 137 & Kruse, 1994 \\
\hline & & $85-140$ & Ehrig et al., 1995 \\
\hline & & $120-150$ & Stegmann, 1982, zit. in Rettenberger \& Mezger, 1992 \\
\hline & & $105-165$ & Jessberger 1992 \\
\hline & & 172 & Tallner, 1993 \\
\hline & & 186 & Pfeffer, 1974, zit. in Rettenberger \& Mezger, 1992 \\
\hline
\end{tabular}

cesses are initiated $\left(\mathrm{MCF}_{\text {begin. of landfilling }}\right)$ by entrapped oxygen in the discharged waste and oxygen supply through the open landfill surface;

- Using data present in literature, a value ranging between 0.8 (thin layer compaction and slow build-up) and 0.95 (fast build-up) can be derived for the MCF respectively MCF $_{\text {begin. of landfilling }}$ (Weber, 1990). According to the IPCC guidelines, the MCF factor is actually based on landfill site management conditions. The IPCC factor of 1 ("Anaerobic managed solid waste disposal sites") does not reflect true conditions in former German landfills;

- When gas production decreases, i.e. in line with age of deposition, increased access of atmospheric air is enabled via the landfill surface mainly by means of wind, temperature and atmospheric pressure changes. This effect is generally greater in the presence of an active gas extraction system (air intake by oversuction effect) $\left(\mathrm{MCF}_{\text {long-term }}\right)$. Moreover, this effect depends on the quality of the surface cover. Many German landfills, and the majority of old deposits, only have a soil cover, at times ameliorated through use of a mineral clay liner.
Only younger landfills currently in the closure and aftercare period are equipped with an impermeable surface geomembrane capable of reducing, although not completely preventing, air access.

The following should be taken into account for the derivation of $\mathrm{MCF}_{\text {long-term }}$ :

- Under strict anaerobic conditions landfill gas would consist almost exclusively of the main components methane and carbon dioxide at a ratio of about 65 to 35 Vol.-\%;

- Available oxygen introduced through air access is converted into carbon dioxide. As a result, the methane-to-carbon-dioxide ratio decreases, with nitrogen present in the landfill gas / air mixture. Figure 3 shows this correlation/relationship, illustrating the change in gas composition due to increased aerobization until the oxygen is almost completely converted. Below the red line, carbon dioxide and methane are the result of anaerobic degradation, above the red line nitrogen and carbon dioxide (with its carbon content $\mathrm{C}_{\text {aerob }}$ ) are due to 


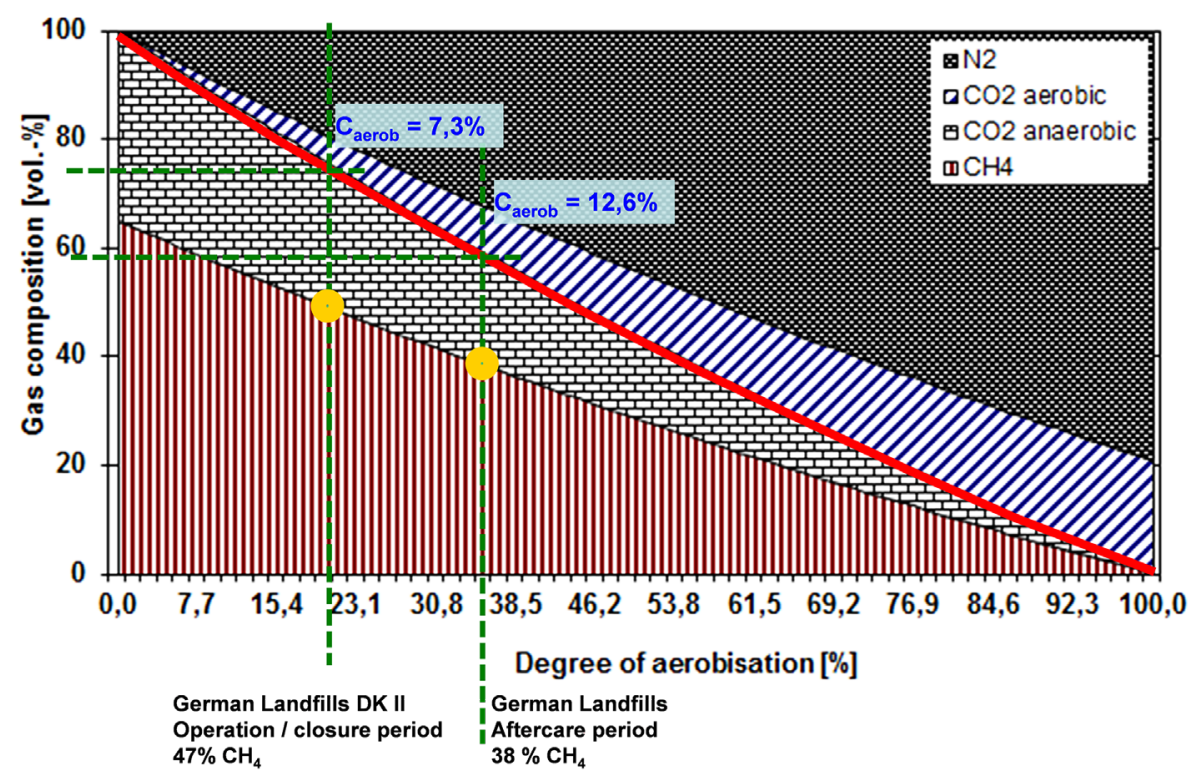

FIGURE 3: Methane content, aerobization degree and fraction of aerobic carbon conversion in German municipal waste landfills, reference year 2014 (DK II landfills correspond to MSW landfills).

air access and aerobic degradation;

- A survey carried out by the Federal Statistical Office for the year 2014 shows that the average methane content of all landfills surveyed during the operational and closure phase is $47 \mathrm{Vol} .-\%$, and of landfills in the aftercare phase $38 \mathrm{Vol} . \%$. The proportion of aerobic degradation estimated for these methane concentrations in relation to total degradation of bioavailable carbon is shown in Figure 3 (7.3-12.6\% of carbon conversion due to aerobically-produced carbon dioxide). For this estimation, it was assumed that oxygen consumption is dominated by aerobic decomposition, with carbon and oxygen reacting at a ratio of $1: 1$;

- Therefore, an actual value for $\mathrm{MCF}_{\text {long-term }} \mathrm{MCF}_{\text {tot. }}$ of 0.93 for younger DK II landfills in the closure period and 0.87 for older landfills in the aftercare period can be deduced with a decreasing tendency (due to the increasing degree of aerobization).

\section{ASSESSMENT BASED ON COLLECTED GAS VOLUMES IN LANDFILLS}

\subsection{Example of the gas content of an encapsulated landfill}

The encapsulated German landfill "ER" displays the following conditions:

- Deposition period 1979-1991

- Area: 40 ha

- Deposition mass: 13 Mio. Mg

- Surface cover since 1995

- 95 vertical gas wells, 42 horizontal gas drainage pipes

Figure 4 shows the amount of carbon present in landfill gas extracted from this landfill compared to the amount of carbon calculated using the gas prognosis approach applied in the previous expert report (see Table 1). Using these data the degree of collection is calculated. Further- more, Figure 4 shows the comparison of carbon degradation over time according to gas prognosis obtained according to the IPCC and German NIR approaches. In line with this evaluation it can be concluded that gas formation hypothesized using the IPCC/NIR approach, particularly from the paper and cardboard fraction, is however significantly over-estimated.

With regard to the "ER" encapsulated landfill, Figure 5 illustrates the percentage of aerobically degraded carbon estimated from methane concentrations in the extracted gas (see Figure 3). Although this landfill displays a high degree of encapsulation, the percentage of aerobic carbon conversion related to total (anaerobic and aerobic) carbon conversion increased from 2 to $14 \%$ within 10 years of application of surface capping.

\subsection{Assessment based on the content of bioavail- able carbon determined by solid waste sampling in landfills}

Sixteen German landfills ("Al"-"OI") with surface liners of varying gas and water permeability were drilled to obtain 449 solid waste samples. The age of deposition of solid waste samples ranged from 5 to 45 years and sampling depth was between 5 and $50 \mathrm{~m}$. The samples were analysed to determine the fraction of currently bioavailable carbon and resulting methane gas formation potential $L_{0}$ with the following methods:

- Total organic carbon (TOC) according to DIN EN 13137; - Respiration activity over 4 days according to the German Landfill Ordinance (DepV, 2009);

- Gas formation test over 21 days according to DIN 38414-8 (DepV, 2009).

Reliable estimations of current landfill gas production rates can be obtained using the results of waste sample analysis in combination with average values for the half- 


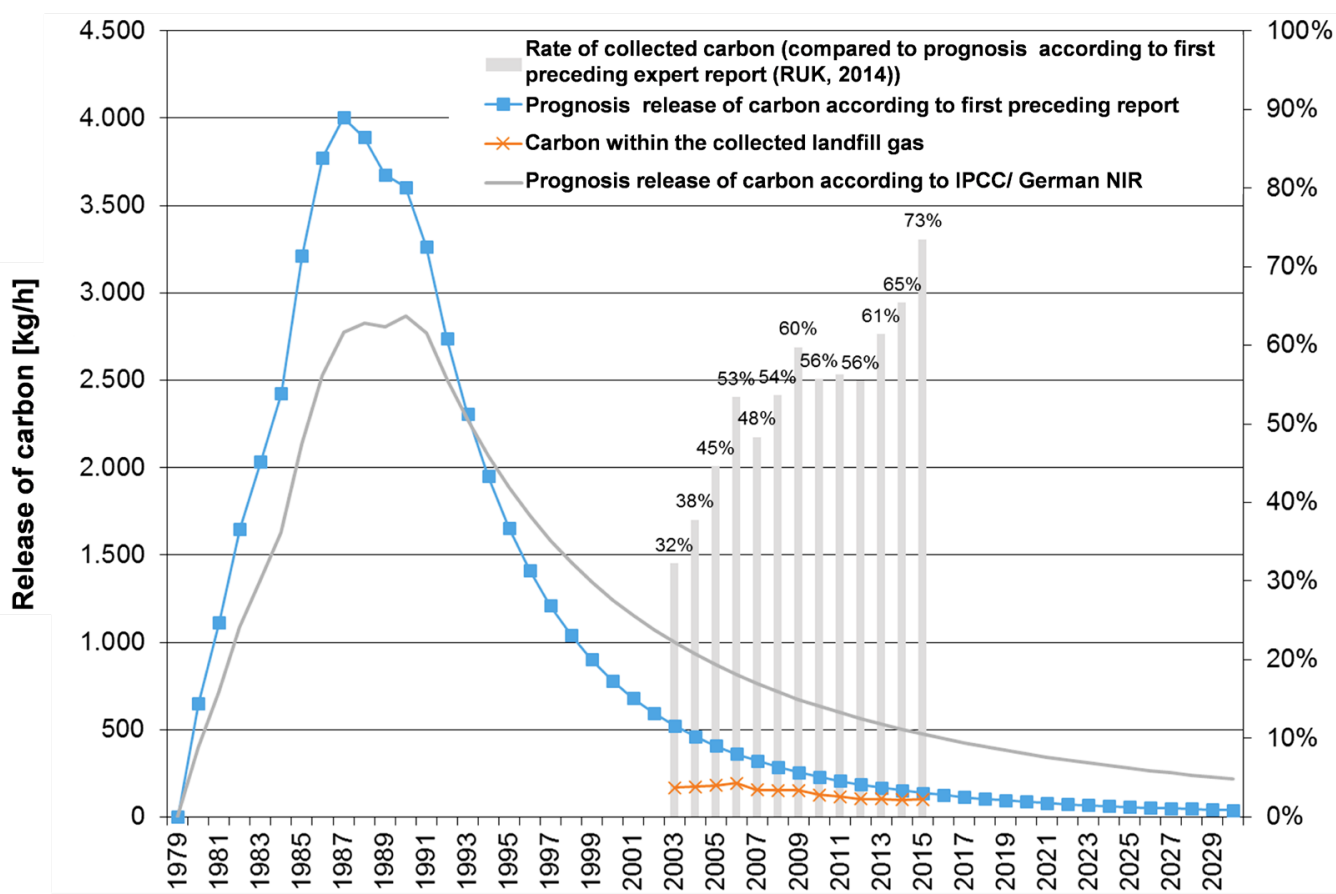

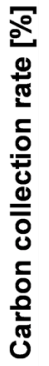

FIGURE 4: Calculated release of carbon and carbon collection rates from an "ER" encapsulated landfill (IFAS \& RUK, 2017).

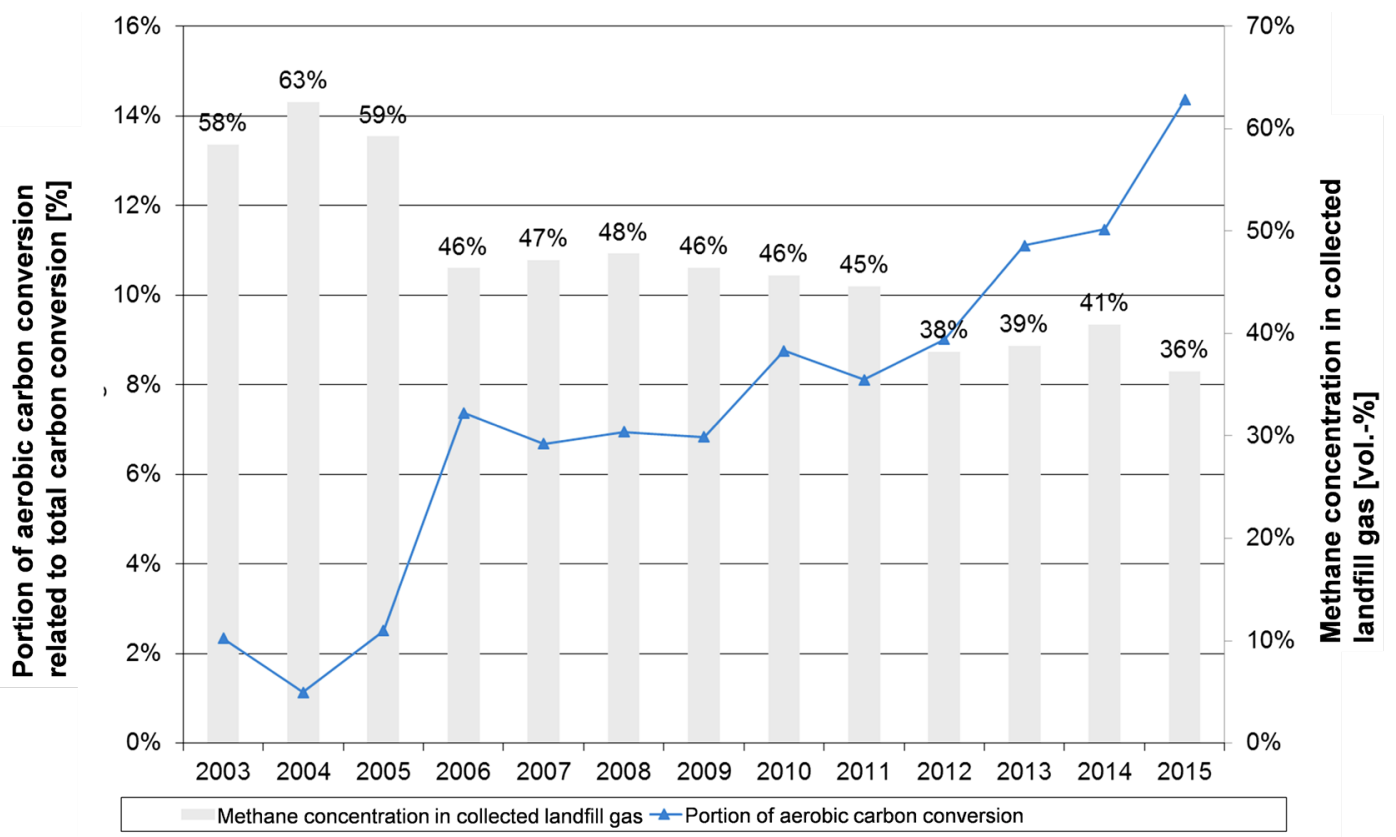

FIGURE 5: Fraction of aerobic carbon degradation in the landfill body due to introduction of atmospheric air into the "ER" encapsulated landfill (IFAS \& RUK, 2017).

life. Current methane formation rate thus obtained is regarded as highly "realistic".

A comparison of methane production rates based on site-specific investigations with gas production prognosis estimated on the basis of IPCC or NIR assumption values (in particular DOC and DOC ) confirmed that IPCC/NIR prognosis resulted in an ambiguously high estimation (approx. 2-fold higher) of methane formation rates.

At many sites, adaptation of $\mathrm{DOC}_{\mathrm{f}}$ and half-life values (from the approach suggested in the previous expert report
(Table 1 ) resulted in a more similar gas prognosis to that derived from solid waste investigations. As an example, this is evident in one of the 16 more closely investigated landfills:

- The landfill "LI" was filled with unpretreated municipal waste from 1971 to 2005 ;

- Landfill gas collection has been implemented since 1993 (Figure 6);

- By applying preliminary adjusted parameter values the 


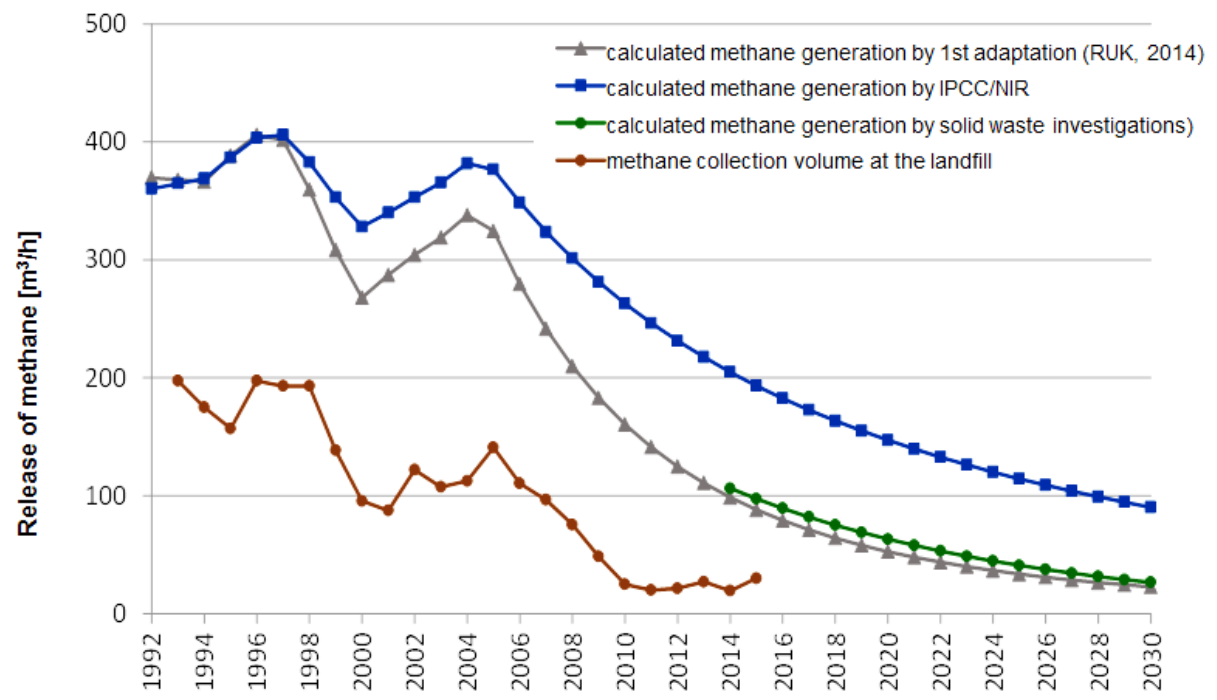

FIGURE 6: Methane production of an "LI" landfill since the year 1993; comparison with gas prog-nosis calculations using IPCC/NIR, with adapted values and results from landfill investigations.

methane production rate for the year 2014 was estimated as $99 \mathrm{~m}^{3} \mathrm{CH}_{4} / \mathrm{h}$;

- Investigation of the solid waste samples obtained from drilling into the landfill in the year 2014 showed an average methane formation potential of $6.2 \mathrm{~m}^{3} \mathrm{CH}_{4} / \mathrm{Mg}$ DM. This resulted for the year 2014 in a methane production of $106 \mathrm{~m}^{3} \mathrm{CH}_{4} / \mathrm{h}$ at an average half-life value of approx. 8 years.

On using the above-described values for a preliminary adaptation of IPCC / NIR default values applied to predict methane production rates, and comparing the results obtained with methane production determined by solid waste sample investigations, remarkably similar curves were obtained. Moreover, average gas collection rates were in a similar order of magnitude.

\subsection{Conclusions regarding the gas collection rate}

A comparison of gas extraction rates yielded by almost fully gas-tight encapsulated landfills with landfills featuring a series of gas-permeable surface liners revealed an average difference in the degree of gas collection ranging from approximately $54 \%$ (encapsulated) to $44 \%$ (different gas permeabilities). This finding may indicate that landfills with a temporary - permeable - surface cover combined with a qualified gas extraction system release only marginally higher methane emissions compared to gas-tight encapsulated landfill sites.

In almost all landfills, the highest uncertainty regarding a gas prognosis is related to the lack of differentiated and reliable information on waste composition of the landfill body. This applies both to the quantity of household waste, commercial waste, sludge, construction and demolition waste, mineral waste, etc., as well as to the composition of the individual waste fractions. Results obtained in landfill investigations in Germany have demonstrated that the proportion, in particular of "paper, cardboard, cardboard packaging" and also "wood and straw" both quantitatively and in relation to methane formation potential is signifi- cantly lower than previously stated in the IPCC / German NIR standard values.

A further reduction of the calculated methane emissions, and consequent increase in the degree of gas collection, could be achieved if aerobic degradation processes were more closely monitored both at the beginning of landfilling and during landfill ageing. By including an average MCF value of 0.8 instead of 1 (as an example) as a simplified fixed factor to reflect the impact of aerobic degradation both at the start of deposition and in the long-term, the resulting increase in gas capture efficiency would be in the range of approximately $25 \%$.

Table 4 provides an overview of the gas collection rates obtained using the different parameter sets, together with the results of solid waste sample investigations for the landfills Al - Ol (different surface sealing and gas permeabilities as well as different gas extraction systems).

\section{CONCLUSIONS, ADAPTATION OF GERMAN NIR DEFAULT VALUES}

Conclusions of the evaluations and investigations performed:

- The review of the methodological basis for use in determining methane formation in landfills is beneficial, as the previous approaches and default values applied in the NIR (and IPCC) reports lead to methane formation rates, which do not reflect but clearly over-estimate the actual conditions of German landfills;

- Assessment of both the state of the knowledge and the literature, as well as the compilation of monitoring results and investigations of numerous waste samples from MSW landfills in Germany have provided confirmation of the above;

- A comparison of methane production rates based on site-specific investigations with gas production prognosis estimated on the basis of IPCC or NIR assumption values (in particular DOC and $\mathrm{DOC}_{\mathrm{f}}$ ) confirmed that 
TABLE 4: Overview of gas collection rates obtained using different parameter sets and results of solid waste sample investigations for the landfills "Al" - "OI".

\begin{tabular}{|c|c|c|c|c|c|c|c|}
\hline \multirow{2}{*}{ Landfill } & \multicolumn{2}{|c|}{$\begin{array}{l}\text { Without adaptation } \mathrm{DOC}_{\mathrm{f}} \text { and } \\
\text { half-life in FOD-Model of the } \\
\text { IPCC }\end{array}$} & \multicolumn{2}{|c|}{$\begin{array}{l}\text { With first adaptation } \mathrm{DOC}_{\mathrm{f}} \text { and } \\
\text { half-life in FOD-Model of the } \\
\text { IPCC (RUK, 2014) }\end{array}$} & \multicolumn{2}{|c|}{$\begin{array}{c}\text { Methane formation potential } \mathrm{L}_{0} \\
\text { from solid waste sampling, } \\
\text { FOD-Model }\end{array}$} & \multirow{2}{*}{$\begin{array}{c}\text { Current gas } \\
\text { collection } \\
\text { volume }\end{array}$} \\
\hline & $\begin{array}{l}\text { Methane } \\
\text { volume } \\
{\left[\mathrm{m}^{3} \mathrm{CH}_{4} / \mathrm{h}\right]}\end{array}$ & $\begin{array}{l}\text { Collection } \\
\text { rate } \\
{[\%]}\end{array}$ & $\begin{array}{l}\text { Methane } \\
\text { volume } \\
{\left[\mathrm{m}^{3} \mathrm{CH}_{4} / \mathrm{h}\right]}\end{array}$ & $\begin{array}{l}\text { Collection } \\
\text { rate } \\
{[\%]}\end{array}$ & $\begin{array}{l}\text { Methane } \\
\text { volume } \\
{\left[\mathrm{m}^{3} \mathrm{CH}_{4} / \mathrm{h}\right]}\end{array}$ & $\begin{array}{l}\text { Collection } \\
\text { rate } \\
{[\%]}\end{array}$ & \\
\hline $\mathrm{Al}$ & 186 & $16 \%$ & 84 & $36 \%$ & 47 & $64 \%$ & 30 \\
\hline BI & 185 & $19 \%$ & 96 & $38 \%$ & 75 & $48 \%$ & 36 \\
\hline $\mathrm{Cl}$ & 131 & $23 \%$ & 46 & $65 \%$ & 69 & $43 \%$ & 30 \\
\hline DI & 145 & $17 \%$ & 101 & $25 \%$ & 57 & $44 \%$ & 25 \\
\hline El & 131 & $10 \%$ & 64 & $20 \%$ & 50 & $26 \%$ & 13 \\
\hline $\mathrm{FI}$ & 202 & $27 \%$ & 114 & $48 \%$ & 83 & $66 \%$ & 55 \\
\hline GI & 200 & $14 \%$ & 60 & $45 \%$ & 86 & $31 \%$ & 27 \\
\hline $\mathrm{HI}$ & 669 & $57 \%$ & 343 & $111 \%^{(1)}$ & 450 & $84 \%$ & 380 \\
\hline II & 196 & $36 \%$ & 89 & $79 \%$ & 112 & $63 \%$ & 70 \\
\hline 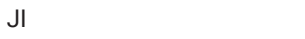 & 255 & $16 \%$ & 104 & $38 \%$ & 94 & $43 \%$ & 40 \\
\hline $\mathrm{KI}$ & 208 & $14 \%$ & 102 & $29 \%$ & 95 & $32 \%$ & 30 \\
\hline LI & 205 & $15 \%$ & 99 & $30 \%$ & 106 & $28 \%$ & 30 \\
\hline MI old section & 1845 & $8 \%$ & 625 & $24 \%$ & 796 & $19 \%$ & 148 \\
\hline MI new section & 1703 & $30 \%$ & 1063 & $48 \%$ & 813 & $63 \%$ & 511 \\
\hline $\mathrm{NI}$ & 47 & $11 \%$ & 27 & $19 \%$ & 29 & $17 \%$ & 5 \\
\hline OI & 137 & $15 \%$ & 65 & $31 \%$ & 53 & $38 \%$ & 20 \\
\hline Range & & $8-57 \%$ & & $19-(111) \%$ & & $19-84 \%$ & \\
\hline Mean value with $\mathrm{MCF}=1$ & & $21 \%$ & & $42 \%$ & & $44 \%$ & \\
\hline Mean value with $\mathrm{MCF}=0.8$ & & $26 \%$ & & $53 \%$ & & $55 \%$ & \\
\hline
\end{tabular}

(1) The higher gas collection volume compared to the modified gas prognosis calculation is likely due to the uncertainty of waste composition of this landfill.

IPCC/NIR prognosis resulted in an ambiguously high estimation (approx. 2-fold higher) of methane formation rates;

- Indeed, the estimation of current and prediction of future methane emissions for a series of closely monitored landfill sites using the modified approaches for methane formation potential and its kinetics (first preceding approach, RUK 2014) have already proven to be a good fit with the findings of biotests on solid waste samples taken from landfills;

- For a more realistic prognosis and calculation of the methane formation potential and methane formation in landfills the following parameters may be adapted for the individual organic waste fractions:

- DOC

- DOC

- Half-life

- MCF

The adaptations discussed for each of the relevant parameters are summarized in Table 5 . In particular, a standard $D O C_{f}$ value of $0.5(50 \%)$ for all fractions is not realistic. The fraction of readily degradable waste is substantially higher than the fraction of scarcely degradable

TABLE 5: Comparison of approaches applied in the German National Inventory Report (NIR) and suggestions put forward by the authors for modified parameters to quantify methane formation.

\begin{tabular}{|c|c|c|c|c|c|c|}
\hline \multirow{2}{*}{ Waste type } & \multicolumn{3}{|c|}{ Values in the German NIR (UBA, 2017) } & \multicolumn{3}{|c|}{ Proposed values for adaptation } \\
\hline & Half-life (years) & DOC $_{f}$ & DOC & Half-life (years) & DOC $_{f}$ & DOC \\
\hline Food waste & 4 & 0.5 & 0.18 & 4 & 0.5 & 0.18 \\
\hline Garden & 7 & 0.5 & 0.2 & 7 & 0.5 & 0.2 \\
\hline Paper & 12 & 0.5 & 0.4 & 7 (rather 4) & 0.5 & 0.4 \\
\hline Wood and straw & 23 & 0.5 & 0.43 & 50 & 0.1 & 0.43 \\
\hline Textiles & 12 & 0.5 & 0.24 & 10 & 0.4 & 0.24 \\
\hline Disposable nappies & 12 & 0.5 & 0.24 & 10 & 0.4 & 0.24 \\
\hline Sewage sludge & 4 & 0.5 & 0.05 & 4 & 0.5 & 0.15 \\
\hline Composite materials & 12 & 0.5 & 0.1 & 12 & 0.4 & 0.1 \\
\hline MBP-Residues & 12 & 0.5 & 0.023 & 12 (rather 4) & 0.5 & 0.023 \\
\hline
\end{tabular}


waste. Moreover, a simplified fixed MCF value of 0.8-0.9 instead of 1 should be considered in order to reflect the impact of aerobic degradation at the start of deposition and in the long-term.

When the adapted values are used to estimate methane emissions from German landfills, they yield a result in a range of only $50 \%$ compared to estimations obtained with the German NIR values applied to date.

\section{REFERENCES}

Barghoorn, M, Gössele, P. Kaworski, W. (1986). Bundesweite Hausmüllanalyse 1983 bis 1985 . Forschungsbericht 10303508. Umweltbundesamt Berlin, 1986.

Baumeler, A.; Brunner, P.H.; Fehringer, R.; Kisliakova, A., Schachermayer E. (1998). Reduktion von Treibhausgasen durch Optimierung der Abfallwirtschaft ( $\mathrm{CH} 4)$. Schriftenreihe der Energieforschungsgemeinschaft im Verband der E-Werke Österreichs, Nr.: 650/457.

BLfU (2003). Zusammensetzung und Schadstoffgehalte von Siedlungsabfällen. Bayerisches Landesamt für Umwelt (eds.).

Butz, W. (2014). Der Beitrag der Abfallwirtschaft zum Klimaschutz. Deponietechnik 2014. Eds. Stegmann, Rettenberger, Kuchta, Siechau, Fricke, Heyer. Hamburger Berichte 40, Verlag Abfall aktuell p. $35-43$.

DepV (2009). Verordnung über Deponien und Langzeitlager (Deponieverordnung / German Landfill Ordinance), 27. April 2009 (BGBI. I S. 900).

DESTATIS (2017). Umwelt. Abfallentsorgung 2015. Fachserie 19 Reihe 1. Statistisches Bundesamt. 07. July 2017.

Ehrig, H.-J. et al. (1995). BMBF-Statusbericht - Teil 1, Statusbericht Deponiekörper. p.116. (not published).

IFAS \& RUK (2017). Review of methodological basis for determining the methane production in landfills $-1^{\text {st }}$ Version Final Report for the year 2017 for the German Environmental Protection Agency, Project No. 3714343170, not yet published.

IPCC (2006). 2006 IPCC Guidelines for National Greenhouse Gas Inventories, chapter 3 volume 5, see: http://www.ipcc-nggip.iges. or.jp/ public/2006gl/pdf/5_Volume5/ V5_3_Ch3_SWDS.pdf

Kruse, K. (1994). Langfristiges Emissionsgeschehen von Siedlungsabfalldeponien, Heft 54 des Instituts für Siedlungswasserwirtschaft, Technische Universität Braunschweig, ISSN 0934-9731.

Jessberger, H.-L. (1992). Zwischenbericht des Forschungsprojektes Geotechnik der Abfallstoffe. September 1992.
Krause, M.J., Chickering, G.W., Townsend, T.G., Reinhart, D.R. (2016). Critical review of the methane generation potential of municipal solid waste. Critical Reviews in Environmental Science and Technology. S. 1117-1182, DOI: 10.180/10643389.2016.1204812

KTBL (2015). Gasausbeute in landwirtschaftlichen Biogasanlagen. Kuratorium für Technik und Bauwesen in der Landwirtschaft:KTBLHeft 50, 1. edition, Darmstadt.

Lechner, P. (2004). Kommunale Abfallentsorgung. UTB 2114. Facultas Universitätsverlag, Wien.

Nelles, M.; Harant, M.; Hofer, M.; Lorber, K. E.; Raninger, B. (1998). Mechanisch-biologische Restabfallbehandlung zur Umsetzung der Deponieverordnung. IED Schau. Schriftenreihe Abfall - Umwelt. Institut für Entsorgungs- und Deponietechnik der Montanuniversität Leoben.

Oonk, H. (2012). Efficiency of landfill gas collection for methane emission reduction, Greenhouse Gas Measurement and Management, 2:2-3, 129-145, DOI: 10.1080/20430779.2012.730798

Ramke, H.G. (2008). Plausibilitätskontrollen in der Analytik von Zuordnungsparametern fester Siedlungsabfälle. Fachgespräch Feststoffuntersuchung 2008. Symposium Bildungsstätte Essen, BEW Bildungszentrum für Entsorgungs- und Wasserwirtschaft $\mathrm{GmbH}$, Essen, 21./22. April 2008.

Ramke, H.G. (2010). Hydrothermale Carbonisierung. Abschlussbericht. Hochschule Ostwestfalen-Lippe. Fachbereich Umweltingenieurwesen und Angewandte Informatik. Höxter, October 2010.

Rettenberger, G., Mezger, H. (1992): Der Deponiegashaushalt in Altablagerungen - Leitfaden Deponiegas. Herausgegeben von der Landesanstalt für Umweltschutz Baden-Württemberg. 1. edition. Karlsruhe.

RUK (2014). Überprüfung der Emissionsfaktoren für die Berechnung der Methanemissionen aus Deponien. Expert Report for the German Environment Protection Agency, project 21980, January 2014 (not published).

Spendlin, H.-H. (1991). Untersuchungen zur frühzeitigen Initiierung der Methanbildung bei festen Abfallstoffen, Hamburger Berichte 4, ISBN 3-87081-271-0, Economica Verlag, Bonn.

Tallner, L. (1993). Produktion und Nutzung von Deponiegas. http:// lotall.bplaced.com/lotall/dgas/index-d.htm, last access 04/2018

UBA - Umweltbundesamt (2017). Submission under the United Nations Framework Convention on Climate Change and the Kyoto Protocol 2017, National Inventory Report for the German Greenhouse Gas Inventory 1990 - 2015, German Environment Agency - UNFCCCSubmission, April 2017.

Weber, B. (1990). Minimierung von Emissionen der Deponie, Veröff. des ISAH, Universität Hannover, Nr. 74, 1990. 